Using historical and statistical data, the state of public education in the Old Village (Stare Selo) is considered. It is stated that the Old Village is the oldest settlement in Sumy region, the name of which accurately reflects its history. The Old Village is a noble nest of the Kondratiev-Zboromyrskyi family, from where the history of not only the city of Sumy, but the whole region began. However, although the Old Village was the first settlement in these territories, it did not lead forward in educational work. It was only thanks to the assistance of the rural community that a public school was opened here.

Further studies should be aimed at a deeper analysis of public education in the Old Village.

Key words Sloboda Ukraine, settlement, first settlement, Old Village, public education, education, student, teacher.

$$
\text { удк 37.02:378.4(477-81) }
$$

Оксана Нефедченко

Сумський державний педагогічний університет імені А. С. Макаренка ORCID ID0000-0003-1656-2422

DOI 10.24139/2312-5993/2019.07/366-380

\title{
СТАНОВЛЕННЯ ТЕХНОЛОГІЙ ЕВРИСТИЧНОЇ ОСВІТИ В УКРАЇНСЬКІЙ ВИЩІЙ ПЕДАГОГІЧНІЙ ШКОЛІ
}

У статті здійснено аналіз розвитку основних ідей і технологій евристичної освіти у вітчизняній педагогіці. На основі історико-генетичного та історикопорівняльного аналізу виокремлено основні етапи становлення й розвитку евристичної освіти з їі технологіями евристичного навчання в українських закладах вищої освіти (ЗВО), зокрема в педагогічних університетах, протягом XXXI століття. Узагальнено тенденції розвитку інноваційних технологій евристичної освітньої системи зі ствердженням пріоритетів пізнавально-творчої і профресійнотворчої діяльності, спрямованої на підготовку креативної особистості майстерного, гуманістично спрямованого педагога.

Ключові слова: технології евристичної освіти, вітчизняна педагогіка, заклади вищої освіти (ЗВО), пізнавально-творча і профресійно-творча діяльність, креативний, гуманістично спрямований педагог.

Постановка проблеми. Україна як самостійна, демократична держава переживає еру модернізації, великих змін, які супроводжуються суттєвими реформами в кожній життєвій сфері - економіці, медицині, інженерії, у сфері ІТ-технологій, агрономії тощо. Безумовно, освіта як надійний фундамент становлення та розвитку громадянина високорозвиненої країни має займати ключове місце в суспільстві, створювати нову, творчо-гуманістичну освітню систему замість застарілої, авторитарної, переважно монологічної системи навчання й виховання підростаючого покоління. Але хто буде навчати таку молодь творчо та критично мислити, знаходити нестандартні підходи в розв'язанні складних ситуацій і проблем? Лише сучасний педагог, звільнений від шаблонів мислення та страху сказати «щось не те», здатний виховувати самодостатню, творчу особистість 3 іï постійним прагненням до 
самореалізації та самовдосконалення. У державних документах - Законах України «Про вищу освіту» (2014), «Про освіту» (2017), у Концепції «Нова українська школа» (2016) - окреслено основні шляхи зміни існуючої традиційної репродуктивної освітньої системи підготовки професійних фахівців, використання сучасних технологій здобування, закріплення та використання знань, коли всі освітні суб'єкти співпрацюють між собою в продуктивній самостійній пізнавально-творчій, професійно-творчій, дослідницькій діяльності. На жаль, реформаторські проекти на державному та інституціональному рівнях реалізуються надто повільно, тому що немає чіткої стратегії поступового, але рішучого впровадження інновацій на кожному етапі розвитку національної освітньої системи.

Аналіз актуальних досліджень. Досліджуючи евристичну освіту та ії технології, ми поділяємо позицію вітчизняних учених (Н. Гузій, І. Зязюн, Б. Коротяєв, Л. Король, В. Курило, М. Лазарєв, В. Лозова, А. Сбруєва, Н. Тарасевич та ін.), що саме заклади вищої педагогічної освіти, у першу чергу, потребують суттєвої модернізації, упровадження інноваційних ідей і технологій у всіх компонентах освітнього процесу. Видатний вітчизняний педагог П. Ф. Каптерєв (Каптерєв, 1982) доводив, що саме евристична модель педагогічного процесу потрібна національній освіті, щоб розкріпачити молоде покоління, навчити вільно мислити та творчо й відповідально підходити до учіння і праці. П. Каптерєв першим із вітчизняних педагогів виступив за вивчення й застосування сократівської філософії і педагогіки діалогічно-дослідницького навчання. Його теоретичні та методичні розробки щодо евристичних форм і методів навчання актуальні й на сьогодні. Тому, на думку проф. Б. Коротяєва (Коротяєв, 2013) та проф. В. Лозової (Лозова, 2000, с. 44-45), потрібні нові стратегії, умови і моделі освіти й навчання, ствердження нових відносини між усіма суб'єктами освіти. Означені та інші автори (Н. Гузій, І. Зязюн, І. Кривонос, А. Сологуб, Н. Тарасевич, А. Хуторськой) стверджують необхідність розробки і практичної побудови нової системи освіти майбутніх фахівців у вищій школі з постійним використанням у цій системі переважно технологій евристичної діяльності, евристичного діалогу, дослідницьких методів індивідуальної праці і співпраці з іншими. Але не можна не звернути увагу на дуже повільну й непослідовну модернізацію освітнього процесу у вищій школі, де парадигма і технології евристичного навчання не стали центральною подією життя сучасного університету. Тому в педагогічній науці стають затребуваними дослідження, присвячені становленню концепцій і технологій нового типу освіти - освіти евристичної з іï різними варіантами - евристично-модульне чи проблемно-евристичне навчання, креативна освіта, евристично-дослідницька освіта тощо.

Мета статті - виявити основні тенденції становлення й розвитку основних концепцій і технологій евристичної освіти як цілісної системи інноваційної, особистісно-орієнтованої підготовки творчої особистості 
майбутнього педагога в українських закладах вищої педагогічної освіти в кінці XX - у перші десятиліття XXI століття.

Методи дослідження: аналіз, синтез, порівняння, узагальнення, систематизація, історико-генетичний, парадигмальний, синергетичний методи для дослідження проблеми розвитку технологій евристичної освіти в українських педагогічних вишах.

Виклад основного матеріалу. У традиційній освіті, через яку пройшли багато поколінь українців, ми звикли більше слухати, переказувати, запам'ятовувати теоретичний матеріал і факти, часто не розуміючи зміст почутого чи написаного. У традиційній системі майже не було реального діалогу між педагогом та вихованцями, завдяки якому суб'єкти навчання вчаться формувати й висловлювати власну думку, ставити суттєві запитання, уважно вислуховувати товариша, приходити до спільного, часто компромісного, рішення. Саме евристична форма освіти і навчання (від грец. heurisko - знаходжу, відкриваю), на переконання багатьох учених (Д. Армстронг, Н. Барбаліс, Г. Ващенко, А. Король, А. Хуторськой, П. Фрейре та ін.), здатна внести саме ті зміни, які потрібні сучасній освіті. Ще Сократ навчав своїх учнів здобувати знання шляхом правильно поставлених основних та навідних запитань, проектуючи на основі діалогу першу для учня евристичну форму діяльності. Лише в діалозі, шляхом висловлювання та аналізу власних думок, виокремлення разом зі співрозмовником поля незнаного та основних кроків до вирішення поставленої задачі, народжується істина. Таку конструктивну діяльність - «перехід з небуття в буття» Сократ визначив як «творчість», бо саме таким чином відбувається створення нового, невідомого раніше продукту - знання. Це стало початком народження теорії евристики й евристичного навчання, основою якого $\epsilon$ переважно пізнавально-творча (евристична) діяльность суб'єктів освіти (Лазарєв, 2016). Філософи, педагоги, науковці різних часів (від античності до сьогодення) продовжували та вдосконалювали вчення Сократа, теоретично та практично використовували евристичний метод у власних наукових теоретичних та практичних дослідженнях, постійно наражаючись на спротив існуючої на той час системи освіти. Але, завдяки незламному духу та твердому переконанню науковцівдослідників в ефективності використання інноваційних технологій, евристичне навчання не просто не втратило своєї актуальності, а й набирає сили у світовій та вітчизняній педагогіці.

Початком становлення евристичної освіти в Україні можна вважати наукові роботи видатного вітчизняного філософа і педагога Григорія Савича Сковороди (1722-1794), який заклав підґрунтя інноваційної демократично спрямованої педагогічної системи з гуманістичними принципами та творчими методами навчання й виховання молодого покоління. Виховати щасливу, «для себе і братії своєї корисну» людину - мета будь-якої школи, на думку національного генія. Для досягнення цього, «справся сам із собою. Узнай 
себе... смотри тоє, що тобі сходне... без сродності все ничто» (Сковорода, 1961, с. 324, 327). Щасливою повинна бути кожна людина, незалежно від віку, статі та соціального положення. I лише «сродна праця», тобто природовідповідна діяльність як у навчанні, так і в професійній діяльності, допоможе отримати бажаний результат. «Щаслив, кто сопряг сродную себе частную должность с общею. Сия есть истинная жизнь» (Сковорода, 1961, с. 327). На думку Г. Сковороди, «сродна» праця, безумовно, включає процес учіння як поєднання засвоєння чужих знань та власного досвіду, створення за допомогою природних індивідуальних умінь власної картини світу. Крім «сродної» праці для педагога була вкрай важлива справжня свобода особистості: свобода думки, слова, учинків, вільних, не обмежених шаблонами дій у створенні власного, ні з чим не схожого, продукту розумової або фізичної діяльності.

Петро Федорович Каптерєв (1849-1922) - вітчизняний педагогдослідник, вважав евристичне навчання новою і необхідною формою всієї освіти кінця XIX - початку XX століття. «Евристична форма навчання $€$ така, за якою наукові закони, формули, правила й істини відкриваються та виробляються самими учнями під керівництвом учителя. Зовнішній вид цієї форми в народній школі - запитання-відповіді (еротематичний). Запитання в більшості - навідні» (Каптерев, 1990, с. 221). Ученим було сформульовано декілька правил евристичного методу навчання: «а) як скоро відома наукова істина знайдена, її потрібно зараз же вдягати у строгу і струнку формулу. Інакше учні розумітимуть ії, будуть у змозі вказати дорогу до ії відкриття, але не будуть у змозі виразити ії повно і разом стисло, зв'язно і ясно, унаслідок чого вони і не будуть повними володарями їі в кожен даний момент; б) не потрібно бути педантом у проведенні евристичної форми навчання, але потрібно кожну дрібницю, кожну незначну вводну думку обов'язково вивести, відкрити (виділено нами - О.Н.)» (Каптерев, 1990, с. 220).

Григорій Григорович Ващенко (1878-1967) - один із творців української освітньо-виховної системи, з одного боку, підтримував використання сократівського методу в педагогічній практиці, бо він розвиває логічне мислення як учнів, так і їх наставників, уміння виокремити з великої кількості запропонованих ідей та кроків до вирішення поставленої мети саме ті, які приведуть до бажаного результату. Але, з іншого боку, учений припускає, що молода людина без достатнього життєвого досвіду, може і не мати тих прихованих ймовірних знань, які потрібно знайти та пробудити. Тому педагогу, по-перше, потрібно постійно покращувати свою професійну діяльність, удосконалювати власні вміння поставити конкретні, більш глибокі, мотивовані запитання своїм учням. По-друге, учителю слід навчити, надихнути власним прикладом вихованців чітко формулювати власні нагальні запитання для конструктивного діалогу, показати важливість такого виду освітньої діяльності, зацікавити кожного в спільній творчій роботі. «У 
процесі навчальної роботи іноді буває доцільним стимулювати учнів, щоб вони не тільки відповідали на запитання вчителя, а й самі ставили йому запитання (виділено нами - О.Н.). У таких випадках лекція може набути характеру вільної бесіди, що сприяє підвищенню зацікавленості учнів тією чи іншою дисципліною та збільшенню активності їх у навчанні. Зрозуміло, що зловживати таким засобом не слід, бо тоді навчання загубило $б$ свою систематичність» (Ващенко, 1997, с. 254-255).

На основі дослідження історії розвитку концепцій і технологій евристичної освіти в українській педагогіці в кінці XX - на початку XXI століття ми виокремили такі етапи розвитку вищезазначених концепцій і технологій евристичної освіти.

І етап (60-ті - середина 70-х рр. XX ст.) - формування основних ідей і технологій проблемного та евристичного навчання на основі сократівського діалогічного методу та ідей творчої співпраці учителя й учнів (В. Сухомлинський, Ш. Амонашвілі, І. Іванов, В. Шаталов, Б. Коротяєв).

II етап (кінець 70-х - 80-ті рр. XX ст.) - подальший розвиток ідей навчального діалогу та впровадження в освітню діяльність концепцій творчої самореалізації сутнісних сил особистості як основної мети освіти, переважно освіти евристичної (В. Андреєв, І. Зязюн, І. Кривонос, В. Лозова, Н. Тарасевич).

III етап (90-ті рр. XX - перші десятиліття XXI ст.) - інтеграція й оновлення евристичних та проблемно-евристичних концепцій і технологій вищої освіти, удосконалення навчального діалогу системою способів запитальної діяльності, дослідження змістових елементів і різних видів евристичної діяльності (пошукової, реконструктивної, конструктивної, креативної) для професійної підготовки вчителя - творця і майстра (Н. Гузій, Б. Коротяєв, В. Лозова, М. Лазарєв, Н. Тарасевич, А. Хуторськой), поєднання евристичної освіти з сучасними концепціями університетської педагогічної освіти, зокрема, креативні теоретичні і методичні розробки нових технологій для підготовки докторів філософії О. Дубасенюк А. Сбруєвої, О. Антонової, О. Заболотної та ін. (Лазарєв та Нефедченко, 2018).

Огляд формування основних концепцій і технологій евристичної освіти в сучасній українській педагагоці в кінці минулого та на початку поточного століття логічно розпочати з аналізу наукових ідей Василя Олександровича Сухомлинського (1918 - 1970) - видатного педагога-новатора, який надавав великого значення самостійній пізнавально-творчій діяльності вчителя й учнів для виховання інтелекту і творчого потенціалу школярів. Мета кожного вчителя, на думку В. Сухомлинського, - навчити підростаюче покоління добувати знання самостійно: досліджувати, аналізувати, синтезувати, виокремлювати головне з великої кількості запропонованих ідей, робити висновки, давати визначення. Видатний педагог вважав, що застосування різних видів самостійної праці учнів є невід'ємною умовою розвитку його 
розуму, пам'яті, творчих здібностей, прихованих талановитих потенцій, кращих рис характеру. «Радість відкриття, здивування перед істиною, здобутою власними силами, дає людині самоутвердження, переживання гордості, поваги до самої себе» (Сухомлинський, 1977, с. 401). Креативна ідея В. Сухомлинського щодо створення для учнів штучних розумових труднощів і розкриття різноманітних шляхів самостійного подолання цих перешкод зацікавила педагогів-дослідників у їх теоретичній та практичній діяльності.

Досліджуючи наукові праці В. Сухомлинського, можна побудувати траєкторію послідовних кроків учителя з організації самостійної діяльності учнів, які є важливими для розвитку і вдосконалення сучасних інноваційних технологій евристичної освіти: обсяг самостійної творчої роботи школярів повинен збільшуватися з кожним роком; самостійна інтелектуальна робота старшокласників повинна мати творчий характер; мету самостійної роботи мають визначати як учитель, так і учні; знання потрібно не запам'ятовувати автоматично, а добувати шляхом самостійного аналізу та синтезу фактів, явищ, понять, розв'язання широкого кола пізнавальних задач, використовувати їх у подальшому дослідженні; на всіх етапах уроку ефективно використовувати різноманітні види самостійної роботи; учень має можливість обрати різне за складністю завдання самостійної роботи (Сухомлинський, 1977, с. 339-343).

Таким чином, В. О. Сухомлинський вже у 60-70 роки минулого століття заклав основи сучасної демократичної освіти, яка грунтується на принципах евристики, гуманізму та самостійній пізнавально-творчій діяльності всіх суб'єктів навчання на кожному етапі освітнього процесу.

Цілісна теорія навчання як творчого процесу всіх його суб’єктів була розроблена вперше у вітчизняній педагогіці відомим і найбільш досвідченим сучасним українським ученим, педагогом-новатором Борисом Івановичем Коротяєвим (1929 р. народження). На думку самого професора, така розробка стала фундаментальною дидактичною концепцією навчання учнів і студентів пізнавально-творчої діяльності. Узагальнюючи теоретичні основи навчання як творчого процесу, автор уже в 70-80 рр. минулого століття розглядав творчу пізнавальну діяльність учнів і студентів як «самостійний пошук і створення чи конструювання якогось нового продукту (в індивідуальному досвіді учня нового, невідомого для нього наукового знання або методу, але відомого, як правило, у суспільному досвіді)» (Коротяев, 2006, с. 4). Основу наукової системи Б. Коротяєва складають уперше розроблені евристичні процедури і операції пізнавальної діяльності: опис предметів та явищ із їх взаємозалежностями; пояснення причин взаємозв'язків пізнавальних об'єктів; передбачення результатів освоєння знань; конструювання їх конкретного застосування під час створення власних освітніх продуктів та їх використання в життєій практиці. Це був сміливий, але розсудливий і вивірений крок до нової освітньої парадигми - парадигми евристичної (пізнавально-творчої) освіти. 
Кінцевим результатом творчої роботи учнів і студентів, на думку Б. І. Коротяєва, слід вважати не тільки створення ними абсолютно нового оригінального продукту (креативний рівень), а й моделювання його з уже існуючих, відомих, засвоєних раніше елементів (рівень перетворювальний). Оцінювати таку евристичну навчальну діяльність можна, лише враховуючи всі зусилля підростаючого покоління - духовні, моральні, фізичні. На думку вченого, «вимірювати результати праці тих, хто навчається, можна лише якісною оцінкою, а не в балах, наприклад, оцінювати їх як видатні, відмінні, хороші, задовільні. Незадовільна оцінка стосовно дітей протиприродна й безглузда...» (Коротяев, 2006).

Б. Коротяєв радикально не погоджувався і нині не погоджується 3 існуючою постановкою мети професійної освіти майбутнього вчителя, закладеної в державних навчальних програмах: якісно засвоїти вже готові знання, уміння і навички, кількість яких зазделегідь визначена міністерством освіти. Така мета, на думку педагога, $\epsilon$ некоректною, недосяжною для багатьох студентів, не сприяє творчому розвитку та самозростанню молодого покоління. Потрібно надати навчально-виховній діяльності нової траєкторії, направити ії на захист і зміцнення здоров'я всіх суб'єктів освітнього процесу.

Доктор философских наук, професор, академік Іван Андрійович Зязюн (1938-2014) та педагоги-однодумці його наукової школи (Н. Тарасевич, Л. Крамущенко, І. Кривонос, Л. Малаканова, В. Семиченко, А. Ткаченко та ін.) належать до представників другого етапу розвитку технологій евристичної освіти XX - початку XXI століття. Учені-дослідники запровадили новий науково-дослідний експеримент з підготовки вчителяпрофесіонала нового типу - самостійної, відповідальної, здатної до самовдосконалення творчої особистості.

На початку експерименту полтавські дослідники ще не мали власно виробленої методологічної і теоретичної платформи і, використовуючи поняття «педагогічна майстерність», спирались на вже існуючі визначення вітчизняних та зарубіжних колег. Але згодом, у 1985 р., кандидат педагогічних наук, професор Ніна Миколаївна Тарасевич (1936р. народження) запропонувала креативну структуру педагогічної майстерності, де виокремила такі взаємопов'язані елементи: педагогічну спрямованість, професійне знання, здібності до педагогічної діяльності, уміння в царині педагогічної техніки (Тарасевич, 1985). А вже у 1989 р. Н. Тарасевич пропонує розглядати сутність педагогічної майстерності 3 позицій особистісно-діяльнісного підходу і визначає педагогічну майстерність як «комплекс властивостей особистості (виділено нами - О. Н.), що забезпечує високий рівень самоорганізації професійної педагогічної діяльності. До таких важливих властивостей ми відносимо: гуманістичну спрямованість діяльності вчителя, його професійні знання, педагогічні 
здібності і педагогічну техніку» (Зязюн, 1989, с. 10). Якщо у своїх перших тлумаченнях поняття «гуманістична спрямованість» Н. Тарасевич обмежилась лише включенням її до складових педагогічної майстерності, то в подальших наукових роботах педагог уперше у вітчизняній педагогіці розкриває складність і багатоаспектність цього поняття: «гуманістична спрямованість особистості кожного вчителя багатоаспектна. Ії̈ становлять ціннісні орієнтації: на себе (самоутвердження себе як вимогливого і кваліфікованого вчителя); на школяра і дитячий колектив; на мету педагогічної діяльності (допомогти учневі організувати свою діяльність, розробити разом з ним ії стратегію)» (Зязюн, 1989, с. 11; Зязюн, 1997, с. 32).

Полтавські дослідники наголошують, що повноцінне педагогічне діалогічне спілкування не тільки багатогранне, але й поліфункціональне педагогічне явище. «Воно забезпечує обмін інформацією і співпереживання, пізнання особистості і самоствердження, продуктивну організацію взаємодії» (Зязюн, 2008, с. 92).

Аналіз інноваційних концепцій і технологій полтавських дослідників щодо професійної підготовки вчителя-майстра з позицій евристичних ідей освіти дозволив нам виокремити основні складові інноваційного підходу, без яких, на думку полтавчан, неможливо розвинути та вдосконалити професійно-творчі якості майбутнього вчителя: формування педагогічного артистизму майбутнього вчителя; формування знань, здібностей та вмінь професійного спілкування, володіння творчим діалогом на всіх етапах навчання та вихованння; формування в усіх студентів достатнього рівня риторичної майстерності і культури педагогічної дії; створення умов та розвиток здібностей до створення і реалізації творчих освітніх продуктів.

Полтавські вчені більше 30 років розробляли та вдосконалювали власну технологію з підготовки не просто вчителя-професіонала, а творчої, нестандартно мислячої людини, здатної надихати вихованців до пошуку, проектування, створення, використання нового, відкритого лише власними зусиллями, знання. Якщо на початку експерименту полтавчани надавали перевагу театральній педагогіці та ії технологіям, то в подальшому увага дослідників найбільше була сконцентрована на формуванні та розвиткові творчих якостей саме майбутнього вчителя-професіонала: умінь професійно побудувати педагогічний діалог, використати діалогічні вміння для досягнення високих навчальних успіхів, для запобігання й подолання конфліктних ситуацій, для конструювання ефективних моделей виховних справ тощо (Н.Тарасевич, Л.Король, Л.Крамущенко, І.Кривонос, Л. Малаканова, Л. Савенкова, А. Ткаченко).

Зав. кафедри педагогічної майстерності проф. Н. М. Тарасевич у 2012 р. у звіті для Міністерства освіти і науки України узагальнила основну мету й завдання підготовки сучасного професійного вчителя: «Робиться ставка на педагога - активного перетворювача дійсності, носія культурних 
цінностей і гуманітарних пріоритетів... тому необхідно забезпечити реальну підготовку: педагога-дослідника, ...; педагога-психолога, ...; педагогамайстра, ...» (Тарасевич, 2012).

Педагоги наукової школи І. Зязюна і Н. Тарасевич наповнили своїми значущими напрацюваннями практично-дослідницьку скарбницю інноваційних ідей і технологій евристичної освіти та надали поштовх своїм колегам-новаторам з інших ЗВО України розвивати діалогізацію й демократизацію освітнього процесу, спираючись на творчість та педагогічну майстерність педагога.

Науково-педагогічна діяльність доктора педагогічних наук, професора Валентини Іванівни Лозової та ії наукової школи (Харківський національний педагогічний університет ім. Г.С. Сковороди) може бути віднесена, на нашу думку, до II і III етапів розвитку вітчизняних концепцій і технологій евристичної освіти. В. Лозова першою у вітчизняній педагогіці багатоаспектно і тривало досліджувала проблему розвитку пізнавально-творчої активності учнів і студентів за допомогою технологій проблемного та евристичного навчання. На відміну від російського професора А. Хуторського, учена не протиставляє проблемні та евристичні методи й технології навчання в освітньому процесі, а пропонує діалектично їх поєднувати, не заперечуючи при цьому використання інформаційно-пояснювальних методів.

Основною метою педагогічного процесу, на думку В.І. Лозової, $\epsilon$ створення відповідних умов для успішної самореалізації підростаючого покоління, розвиток основних пізнавально-творчих здібностей, умінь, особистих якостей школярів і студентів. Учені наукової школи членакореспондента НАПН України проф. В. Лозової методологічною основою навчально-виховного процесу вважають сформовану на сьогодні теорію творчої самореалізації особистості.

Підсумовуючи масштабну роботу педагогів-дослідників Харківського національного педагогічного університету ім. Г.С. Сковороди, можна виокремити наступні здобутки наукової школи харків'ян.

1. Цілісна теорія формування пізнавальної активності суб'єктів освіти як осмисленої і сталої якості особистості. Майбутній учитель має поступово переключатися з інформаційно-репродуктивних, реконструктивних видів діяльності на розв'язання конструктивних і креативних задач, формуючи при цьому необхідні якості пізнавально-творчої активності (Лозова, 2000).

2. Уперше в історії вітчизняної педагогіки та освіти професійно-творча самореалізація майбутнього педагога широко й досконально розкрита в науковій школі проф. В.Лозової в аспекті всіх основних видів його діяльності - у навчальному та виховному процесах, у творчому спілкуванні суб'єктів освітньої системи, у різних видах виховної і позааудиторної роботи із застосуванням комплексу евристичних і проблемних освітніх методів. 
3. Створено й застосовано систему евристичних технологій для формування у студентів і школярів громадянської зрілості та ініціативи, морального самовдосконалення, культури педагогічного спілкування, умінь самостійно ставити суттєві й значущі запитання, формувати культуру запитальної діяльності тощо (проф. В. Лозова, професори О. Попова, Л. Рибалко, Л. Зеленська, С. Золотухіна, О. Іонова, Г. Троцко та ін.). Серед цих технологій можна виокремити: технології розв'язання складних виховних ситуацій, самостійного вибору коректної громадянської позиції, креативної самоорганізації діяльності майбутнього вчителя та ін.

у 1993 році на базі Сумського державного педагогічного університету імені А.С. Макаренка було засновано кафедру педагогічної творчості, ії очолив професор Микола Остапович Лазарєв. Саме тоді науковець у співпраці зі своїми викладачами-однодумцями й аспірантами розробив систему методологічних і теоретичних ідей підготовки сучасного вчителя на базі освоєння і застосування концепцій і технологій педагогічної творчості.

Професор М. Лазарєв вперше розглядає евристичну освіту і їі складову евристичне навчання - у системі різних методологічних позицій і підходів: а) у загальнометодологічному аспекті - це цілісна, нелінійна й нерівноважна система освітньої діяльності, стратегія якої спрямована на самореалізацію творчого потенціалу особи, тобто спроможності створювати особистісно значимі освітні продукти (зовнішні і внутрішні); б) в історико-педагогічному аспекті - це новий і прогресивний феномен розвитку теорії і практики педагогічної науки, у змісті і структурі якої збережено й удосконалено раніше здобуті надбання - сократівсько-діалогічного, проблемного, проектного, інтерактивного навчання - і стверджуються нові пріоритети пізнавальнотворчої і професійно-творчої діяльності освітніх суб'єктів; в) у процесуальнотехнологічному аспекті - це динамічна єдність мотиваційно-цільового, проектного, операційного, корекційного і рефлексивно-діагностичного компонентів діяльності, яка включає різні за наростаючою складністю види творчої праці: пошуково-евристичну, перетворювальну (реконструктивну), конструктивну і креативну (Лазарєв, 2018).

Сучасний навчальний процес, на думку сумських науковців, має перетворитися переважно в пізнавально-творчу (евристичну) діяльність всіх його суб'єктів з головною метою - освоєння ними процедур самостійної пошукової, реконструктивної, креативної діяльності. Репродуктивні методи навчання мають бути підпорядковані пізнавально-творчим (евристичним) процедурам, кінцевим результатом яких стають нові, створені власними силами учнів (студентів) освітні продукти. Саме це і $€$ конкретним показником успішності творчої самореалізації підростаючої особистості в освітній системі. Оцінювання такого кінцевого результату має відбуватися не за звичною шкалою балів, а за ступенем завершеності, цілісності освітнього продукту, у якому інтегровані необхідні елементи провідних знань та вмінь. 
Дослідники Сумської наукової школи на чолі з М.Лазарєвим розробили та успішно випробували такі технології евристичного навчання: лекція прямої дії; семінарські і практичні заняття як презентація $і$ захист професійно-творчих освітніх продуктів студентів; педагогічна практика як система проектно-дослідницьких студій учителів-майстрів і майбутніх педагогів (Лазарєв та Лазарєва, 2018).

Варто відзначити відкриту дослідниками полтавської, харківської і сумської наукових шкіл суттєву педагогічну закономірність про взаємообумовленість гуманізму і творчої діяльності: тільки справді гуманістичні стосунки суб'єктів освіти породжують спільні творчі задуми і творчу діяльність вчителя й учнів, викладача і студентів, а творчий процес і його успішні результати, у свою чергу, сприяють закріпленню гуманістичних діалогових відносин, атмосфери психологічного комфорту у педагогічному середовищі. Тобто творчість як евристична, розбудовча діяльність зі створення нового і справжній гуманізм відносин людей неподільні і являють собою найбільш взаємопідсилювальні чинники освітнього життя.

Дослідження полтавських, харківських і сумських науковців доводять, що освіта стає справді евристичною, гуманістичною, результативною за головної умови - досягнення пізнавально-творчої, доброзичливої, майстерної взаємодії наставника й учнів (студентів). А це реально, якщо насамперед педагог сам оволодіє культурою сучасного гуманістичного діалогу та допоможе учням (студентам) освоїти основи запитальної діяльності та діалогічної взаємодії.

У Національному педагогічному університеті імені М. П. Драгоманова в перші десятиліття XXI століття зусиллями науковців кафедри педагогічної творчості на основі досліджень існуючих евристичних концепцій створена, теоретично обґрунтована й задіяна в навчальному процесі новітня система дидаскологічної підготовки майбутнього вчителя. На думку основного автора цієї системи, доктора педагогічних наук, професора Наталії Василівни Гузій, «підготовка педагога-професіонала виступає фундаментальною передумовою реалізації стратегічних завдань освітньої політики країни і належить до пріоритетних напрямів діяльності вищої школи ... Серед різних напрямів професійної підготовки освітянських кадрів, зокрема її педагогічної складової, особливу роль відіграє дидаскалогічна освіта (термін наш, Наталія Гузій) - від «дидаскалогія» - наука про вчителя) - той сегмент навчальновиховного процесу, який безпосередньо презентує студентам теоретичні та технологічні засади педагогічної діяльності, ... за допомогою безпосереднього розкриття цілісних характеристик педагогічної праці 3 орієнтацією на досягнення ії̈ високої якості» (Гузій, 2013, с. 10). Найбільш оптимальною і перспективною технологічною стратегією становлення основ професіоналізму в процесі дидаскалогічної освіти Н. Гузій вважає стратегію педагогічної фрасилітації. Розкриваючи сутність даної стратегії, дослідниця 
доводить, що вона становить альтернативу авторитарно-технократичним педагогічним технологіям «впливу» і навіть «забезпечення», оскільки найповніше відображає унікальність, відкритість професійно-педагогічного зростання студентів і загалом полягає у створенні ефективних педагогічних умов для внутрішньо-особистісних процесів становлення професійної свідомості і самореалізації студентів. Саме тому стратегія фасилітації (допомоги, мотивації) обумовлює особистісний характер технологічного комплексу дидаскалогічної підготовки як дієвої інструментальної основи співробітництва викладача і студента та визначення сукупності адекватних форм, методів, технік, прийомів навчання, що забезпечують перехід від пояснення до розуміння, від монологу до діалогу, від соціального контролю до самоконтролю, від управління до самоуправління (Гузій, 2013, с. 12).

Педагогічні умови для організації підготовки майбутнього педагогафасилітатора, на думку Н. Гузій, передбачають взаємозв'язок технологій проблемного та евристичного навчання. Ці види інноваційної освіти поєднує ідея відходу від пасивно-репродуктивної позиції учня (студента) у здобутті знань, збагачення цього процесу творчими виявами і процедурами, що суттєво активізує пізнавальну діяльність тих, хто навчається, їі когнітивну, емоційно-образну сфери, стимулює розвиток допитливості, фантазії, нестандартного мислення (Гузій, 2013, с. 13).

Висновки. Евристична освіта, започаткована ще Сократом, поступово, але впевнено розвивається та вдосконалюється науковцями та освітянами різних часів, практично використовується педагогаминоваторами в навчально-виховному процесі, адаптуючись під сучасний світ, під кожне, не схоже один на одне покоління підростаючих особистостей. Саме евристична освіта з їі гнучкими інноваційними ідеями та технологіями потрібна оновленій українській вищій педагогічній школі для підготовки вчителя нового типу - дослідника, гуманістично спрямованої, самостійної, творчої особистості, здатної надихати молодь на постійне самовдосконалення та самореалізацію.

Метою евристичної освіти, на думку педагогів-науковців 90-х років XX - початку XXI століття, має стати насамперед створення необхідних умов для успішної творчої самореалізації підростаючого покоління, що передбачає формування пізнавально-творчої активності всіх освітніх суб'єктів, поєднання іiї з професійно-дослідною діяльністю, освоєння студентами і педагогами різних процедур евристичної роботи, оволодіння культурою сучасного педагогічного діалогу.

Виокремлені нами етапи розвитку концепцій і технологій евристичної освіти в українській педагогіці в кінці XX - на початку XXI століття дозволяють виокремити основні тенденції становлення евристичних технологій: ствердження в освітньому процесі пріоритету творчої діяльності над репродуктивною, конструктивного, гуманістичного діалогу над монологом, 
інтеграція мотиваційно-цільового, операційного, корекційного і рефлексивно-діагностичного компонентів евристичної освіти, яка включає різні за наростаючою складністю види творчої праці - пошуково-евристичну, перетворювальну (реконструктивну), конструктивну і креативну; необхідність комплексного застосування означених видів евристичної діяльності для підготовки педагога нового типу - дослідника, психолога-фасилітатора, креативного майстра-професіонала.

\section{ЛІТЕРАТУРА}

Ващенко, Г. Г. (1997). Загальні методи навчання: підручник для педагогів. Київ. Українська Видавнича Спілка (Vashchenko, Н. Н. (1997). General teaching methods: a textbook for teachers. Kyiv: Ukrainian Publishing Union).

Гузій, Н. В. (2013). Проблемно-евристична спрямованість методичного арсеналу дидаскалогічної підготовки. У М.О.Лазарєв (Ред.), Професійно-творча самореалізація майбутнього педагога в інноваційній освіті, (сс. 10-27). Суми (Huzii, N.V. (2013). Problem-heuristic orientation of the methodological arsenal of didactological training. In M. 0. Lazariev (Ed.), Professional-creative self-realization of the future teacher in innovative education, (pp. 10-27). Sumy).

Каптерев, П. Ф. (1982). Избранные педагогические сочинения. Москва: Педагогика (Kapterev, P. F. (1982). Selected Pedagogical Works. M oscow: Pedagogics).

Каптерев, П. Ф. (1990). Эвристическая форма обучения в народной школе. Антология педагогической мысли России второй половины XIX - начала XX в. Москва (Kapterev, P. F. (1990). Heuristic form of education in a public school. Anthology of Russian pedagogical thought in the second half of the 19th - beginning of the 20th centuries. Moscow).

Коротяев, Б. И. (2013). Взгляд в будущее высшего педагогического образования с позиций теории педагогической философии. Луганск. Изд-во ГУ «ЛНУ имени Tараса Шевченко» (Korotiaiev, В. І. (2013). A look into the future of higher pedagogical education from the standpoint of the theory of pedagogical philosophy. Luhansk: "LNU named after Taras Shevchenko").

Коротяев, Б. И. (2006). учение - прочесс творческий. Избр. пед. соч-я. т. 2. Луганск: Альмаматер (Korotiaiev, B. I. (2006). Learning is a creative process. Luhansk: Alma M ater).

Лазарєв, М. О. (2016). Педагогічна творчість. Суми (Lazariev, M. О. (2016). Pepagogical creativity. Sumy).

Лазарєв, М., Нефедченко, О. (2018). Професійна підготовка майбутнього педагога в контексті сучасної евристичної освіти. Науковий часопис НПу ім. М.П.Драгоманова. Серія 16 творча особистість учителя: проблеми теорії $і$ практики, 31( 41), 84-91 (Lazariev, M., Nefedchenko, O. (2018). Professional training of the future teacher in the context of modern heuristic education. Scientific journal of NPU named after M. P. Drahomanov, Series 16. The creative personality of the teacher: problems of theory and practice, 31 (41), 84-91).

Лазарєв, М., Лазарєва, О. (2018). Особливості і компоненти евристичної освіти у професійній підготовці майбутнього педагога. Науковий часопис НПу імені М.П. Драгоманова. Серія 16. Творча особистість учителя: проблеми теорії $i$ практики: зб. наук. праць, 30 (40), 53-59 (Lazariev, M., Lazarieva. O. (2018). Features and components of heuristic education in the future teacher's professional training. Scientific journal of NPU named after M. P. Drahomanov, Series 16. The 
creative personality of the teacher: problems of theory and practice: selected scientific works, 30 (40), 53-59).

Лозова, В. І. (2000). Цілісний підхід до формування пізнавальної активності школярів. Белгород: Изд-во БелГУ (Lozova, V. I. (2000). A holistic approach to the formation of cognitive activity of students. Belgorod: Publishing House of the BelSU).

Нефедченко, О. І. (2017). Сократівська діалогічна евристика та ї̈ розвиток у зарубіжній та вітчизняній освіті. Педагогічні науки: теорія, історія, інноваційні технології, 132-145 (Nefedchenko, 0. I. (2017). Socratic dialogical heuristics and their development in foreign and native education. Pedagogical sciences: theory, history, innovative technologies, 132-135).

Зязюн, И. А. (Ред.) (1989). Основы педагогического майстерств. Москва: Просвещение (Ziaziun, I. A. (Ed.) (1989). Fundamentals of Teaching M ayistry. M oscow: Enlightenment).

Зязюн, І. А. (Ред.) (1997). Педагогічна майстерність. Київ: Вища школа (Ziaziun, І. А. (Ed.) (1997). Pedagogical Skill. Kyiv: Higher School).

Зязюн, І. А. (Ред.) (2008). Педагогічна майстерність. Київ: СПД Богданова А.М. (Ziaziun, I. A. (Ed.) (2008). Teaching Skills. Kyiv: SPD named after Bordanov A.M .).

Сковорода, Григорій (1961). Твори у 2 томах. Київ: АН УРСР, Т. 2, 327 (Skovoroda, Hryhorii (1961). Works in 2 volumes. Kyiv: AN URSR, vol. 2, 327).

Сковорода, Григорій (1961). Твори у 2 томах. Київ: АН УРСР, Т. 1, 324, 327. (Skovoroda, Hryhorii (1961). Works in 2 volumes. Kyiv: AN URSR, vol. 1, 324, 327).

Сухомлинський, В. О. (1977). На трьох китах. Вибрані твори в п'яти томах. Київ: Рад. школа. Т. 5 (Sukhomlynskyi, V. О. (1977). On three whales. Selected works in five volumes. Kyiv: Sov. school. Vol. 5).

Сухомлинський, В. О. (1977). Народження громадянина. Вибрані твори в п'яти томах. Київ: Рад. школа, Т. 3 (Sukhomlynskyi, V. О. (1977). Birth of a citizen. Selected works in five volumes. Kyiv: Sov. school, Vol. 3).

Тарасевич, Н.Н. (1985). Исследование проблемы формирования основ педагогического майстерства у студентов. Пути совершенствования психолого-педагогической підготовки учителя в свете основних направлений реформы общеобразовательной и профессиональной школы. Полтава (Tarasevich, N. N. (1985). The study of the problem of forming the foundations of pedagogical mayistry among students. Ways to improve the psychological and pedagogical training of teachers in the light of the main directions of reform of the comprehensive and vocational schools. Poltava).

Тарасевич, Н. М. (2012). Теоретична та навчально-методична розробка педагогічної майстерності - нової галузі у педагогіці, її впровадження у практику підготовки і підвищення кваліфікації учителів (Tarasevych, N. M. (2012). Theoretical and educational-methodological development of pedagogical mastery - a new branch in pedagogy, its introduction into the practice of teacher training and advanced training).

\section{PEЗЮME}

Нефедченко Оксана. Становление технологий эвристического образования в украинской высшей педагогической школе.

В статье осуществлен анализ сущностных идей $u$ технологий эвристического образования в отечественной педагогике. На основе историкогенетического и историко-сравнительного анализа выделены основные этапы становления и развития эвристического образования $c$ его технологиями эвристического обучения в украинских учреждениях высшего образования (УВО), в том числе педагогических университетах, в течение XX-XXI века. Обобщены 
тенденции развития инновационной эвристической образовательной системы и ее составляющей - эвристического обучения - с утверждением приоритетов познавательно-творческой и профессионально-творческой деятельности, направленной на подготовку креативной личности гуманистически ориентированного педагога-мастера.

Ключевые слова: технологии эвристического образования, отечественная педагогика, учреждения высшего образования (УВО), познавательно-творческая и профессионально-творческая деятельность, креативный, гуманистически ориентированный педагог.

\section{SUMMARY}

Nefeddhenko Oxana. Formation of techniques of heuristic education in Ukrainian higher pedagogical school.

The article analyzes the basic ideas and techniques of heuristic education in national pedagogy, which is originated and developed on the basis of Socratic dialogue, theory and practice of creative self-realization of personality, ideas and methods of pedagogical creativity. Development and improvement of heuristic techniques have been especially intensified in modern conditions, when the purpose of educational system was the cognitivecreative and professional-creative self-realization of either pupil or student, their ability not to absorb already known knowledge, but to create them on the basis of comprehension of scientific concepts in the process of independent heuristic activity, that is, a complex of search, reconstructive, constructive and creative operations and procedures. The results of scientific schools' of pedagogical universities that developed and implemented innovative techniques of heuristic education are analyzed: lectures of direct action, dialogical humanistic cooperation of all subjects of educational process, creation and protection of creative educational products, techniques of diagnostics and evaluation of cognitive-creative and professional self-realization of personality, techniques of pedagogical practice as pilot projects of both master and future teachers. They laid the foundation for an innovative, democratically oriented pedagogical system with humanistic principles and creative teaching and learning methods, and considered heuristic teaching a new form of education in the late nineteenth and early twentieth centuries.

On the basis of historical-genetic and historical-comparative analysis, the main stages of formation, development and modernization of heuristic education with its techniques of heuristic education in Ukrainian higher education institutions (HEls), in particular pedagogical universities during the XX-XXI centuries, were distinguished.

Priority of creative activity over reproductive in educational process, priority of constructive, humanistic dialogue over monologue, synergy of freedom and responsibility of future specialist became the main tendencies of development of some techniques of heuristic education, which are aimed at training of a new type of a professional teacher - researcher, organizer, psychologist, creative master-professional. It is the heuristic education with its flexible innovative ideas and techniques that needs a refreshed Ukrainian higher pedagogical school to train such type of a teacher.

Key words heuristic education techniques, national pedagogy, higher education institutions (HEls), cognitive-creative and professional-creative activity, creative, humanisticoriented educator. 